\title{
Analisis Efisiensi Saluran Distribusi Melalui Pendekatan Transportasi Pada UMKM Kerupuk Ikan Tengiri Desa Gedangan Kecamatan Kutorejo Kabupaten Mojokerto
}

\author{
M. Fatkhur Rozi ${ }^{1}$, Reny Rizqi Agatin ${ }^{2}$ \\ Fakultas Ekonomi, UIN Maulana Malik Ibrahim Malang, Indonesia
}

\author{
$\bowtie$ Corresponding Author: \\ Nama Penulis: M. Fatkhur Rozi \\ E-mail: izory.moh@gmail.com
}

\begin{abstract}
The rapid development of the business world today requires businesses to determine appropriate and targeted strategies, and the strategy carried out by business actors are expected to be able to face and win the competition in the business world, one of the strategy applied is the distribution channel. Therefore, distribution channel decisions often involve a long-term commitment to other agencies or companies. This study aims to determine the value of the efficiency of the distribution channel with the least cost and Vogel's methods, in addition to knowing the efficient path of the distribution channel with the shortest route model. This research includes descriptive quantitative research through a mathematical approach where the aim is to find out the value of the efficiency of the distribution channel, by taking census technical sampling of 31 businessmen in the fish crackers in the village of Gedangan. Data analysis aims to simplify data processing so that it is easy to read and interpret. Data is collected by observation, interview and documentation. The results of this study indicate that the same minimum total cost is obtained between the least cost and Vogel's method. The shortest distance route model is accomplished in all category.
\end{abstract}

Keywords: efficiency, distribution channel, transportation approach, SMES

\begin{abstract}
Abstrak: Pesatnya perkembangan dunia bisnis saat ini menuntut dunia usaha untuk menentukan strategi yang tepat dan tepat sasaran, strategi yang dilakukan oleh pelaku bisnis diharapkan mampu menghadapi dan memenangkan persaingan di dunia bisnis, salah satu strategi yang diterapkan adalah saluran distribusi. Oleh karena itu, keputusan saluran distribusi seringkali melibatkan komitmen jangka panjang kepada agensi atau perusahaan lain. Penelitian ini bertujuan untuk menentukan nilai efisiensi saluran distribusi dengan metode biaya dan vogel terendah, selain untuk mengetahui jalur efisien saluran distribusi dengan model rute terpendek. Penelitian ini termasuk penelitian kuantitatif deskriptif melalui pendekatan matematis dimana tujuannya adalah untuk mengetahui nilai efisiensi saluran distribusi, dengan mengambil sensus teknik sampling 31 pengusaha di kerupuk ikan di desa Gedangan. Analisis data bertujuan untuk menyederhanakan pemrosesan data sehingga mudah dibaca dan ditafsirkan. Data dikumpulkan dengan observasi, wawancara dan dokumentasi. Hasil penelitian ini menunjukkan bahwa total biaya minimum yang sama diperoleh antara biaya terendah dan metode vogel. Model rute jarak terpendek diperoleh dalam semua kategori.
\end{abstract}

Kata kunci: efisiensi, saluran distribusi, pendekatan transportasi, UMKM

Cara mencitasi:

Rozi, M.F., Agatin, R.R. (2019). Analisis Efisiensi Saluran Distribusi Melalui Pendekatan Transportasi Pada UMKM Kerupuk Ikan Tengiri Desa Gedangan 
M. Fatkhur Rozi, Reny Rizqy Agatin

Kecamatan Kutorejo Kabupaten Mojokerto. Iqtishoduna. Vol. 15 (2): pp. 217236.

\section{Pendahuluan}

Pesatnya perkembangan dunia usaha saat ini mengharuskan pelaku usaha untuk menentukan strategi yang sesuai dan tepat sasaran, strategi yang dijalankan pelaku usaha diharapkan mampu menghadapi dan memenangkan persaingan di dunia usaha. Salah satu kegiatan pemasaran yang banyak diterapkan pada saat ini dan menjadi faktor penunjang bagi keberhasilan penjualan produk adalah kegiatan distribusi. Besar kecilnya margin pemasaran ditentukan banyaknya lembaga pemasaran yang terlibat dalam pemasaran sehingga akan mempengaruhi panjang pendeknya rantai pemasaran (saluran distribusi) dan besarnya biaya pemasaran.

Indrajit dan Djokopranoto (2003) mendefinisikan efisiensi saluran distribusi merupakan pencapaian daya guna yang dilakukan suatu perusahaan dengan menggunakan salah satu alat manajemen yang disebut dengan standarisasi. Menurut Kakiay (2008) terdapat dua metode yang sering digunakan dalam mengukur efisiensi saluran distribusi yaitu metode least cost dan metode vogels. Siswanto (2007) menyebutkan bahwa metode rute jarak terpendek yang merupakan salah satu model jaringan yang dapat digunakan untuk menentukan jarak terpendek dari berbagai alternatif rute yang tersedia.

Berbeda dengan efektivitas, efisiensi menekankan pada penggunaan sumber daya untuk mencapai tujuan, sedangkan efektivitas lebih pada hasil yang dicapai dalam tujuan. Perusahaan dalam menjalankan kegiatannya harus mempunyai ukuran untuk menganalisis situasi ini. Tujuan menganalisis saluran distribusi untuk mengetahui seberapa besar tingkat efisiensi distribusi produk hingga sampai ke konsumen.

Dalam pengukuran efisiensi distribusi, berbagai metode dapat digunakan. Yusanti dkk (2017) menyatakan bahwa metode least cost akan lebih tepat karena perhitungan pada metode tersebut didasarkan pada biaya terendah dari jumlah beban pada setiap perjalanan dari satu penyimpanan barang (depo) menuju ke empat tujuan. Ramadhani (2017) menyatakan bahwa biaya pendistribusian barang bisa diminimumkan dengan metode vogel's hal ini dapat dibuktikan dengan semakin rendahnya biaya transportasi setelah menggunakan metode vogel's daripada sebelum menggunakan metode ini.

Berbeda halnya dengan penelitian yang dilakukan Karo (2015) yang menyatakan bahwa mengoptimalkan biaya pendistribuaian barang untuk solusi awal adalah dengan menggunakan linier programming. Tujuan dari penelitian ini adalah untuk mengetahui efisiensi saluran distribusi (biaya minimum) melalui pendekatan transportasi dengan menggunakan metode 
Analisis Efisiensi Saluran Distribusi...

least cost dan vogels serta untuk mengetahui saluran distribusi yang efisien menggunakan metode rute jarak terpendek pada 31 pelaku usaha UMKM kerupuk ikan tengiri Desa Gedangan, Kecamatan Kutorejo, Kabupaten Mojokerto.

\section{Kajian Pustaka}

\section{Efisiensi Saluran Distribusi}

Indrajit dan Djokopranoto (2003) mendefinisikan efisiensi saluran distribusi merupakan pencapaian daya guna yang dilakukan suatu perusahaan dengan menggunakan salah satu alat manajemen yang disebut dengan standarisasi. Menurut Juwanto (2012) efisiensi adalah berkaitan dengan jumlah pengorbanan yang dikeluarkan dalam upaya untuk mencapai tujuan yang diharapkan. Jika pengorbanan yang dikeluarkan terlalu besar maka dapat dikatakan tidak efisien.

Dalam kaitan efisiensi distribusi, pemrosesan pemesanan dapat menjadi tolak ukur Pemrosesan pesanan secara logis merupakan bagian dari distribusi fisik yang berhubungan erat dengan persediaan, pergudangan dan transportasi. Efisiensi pemrosesan pesanan dapat dicapai bila terdapat cukup tenaga kerja dan sumberdaya bahan yang memadai (Taff:1984).

Menurut Kotler dan Armstrong (1999) terdapat 4 faktor dalam distribusi fisik yang efektif dan efisien:

a. Pengelolaan Pesanan

Sistem pemrosesan pesanan mempersiapkan tagihan dan mengirim informasi pesanan kepada mereka yang membutuhkannya. Gudang yang bersangkutan menerima instruksi untuk mengemas dan mengirimkan barangbarang yang dipesan. Produk yang kehabisan persediaan akan dipesan ulang. Barang yang dikirim akan dilengkapi dengan dokumen pengiriman dan penagihan, yang salinannya didistribusikan ke departemen-departemen terkait.

b. Persediaan

Keputusan persediaan melibatkan pengetahuan akan kapan harus memesan dan seberapa banyak yang harus dipesan. Jumlah pesanan lebih dari biasanya mengakibatkan semakin sedikitnya jumlah pesanan dan biaya pemrosesan pesanan yang lebih sedikit, namun itu juga berarti membesarnya biaya penyimpanan barang. Tingkat persediaan juga memengaruhi kepuasan pelanggan, yang pada akhirnya akan berdampak pada volume penjualan. Masalah utamanya adalah bagaimana memelihara keseimbangan antara menyimpan persediaan terlalu banyak dan terlalu sedikit.

\section{c. Pergudangan}

Fungsi penyimpanan dibutuhkan karena siklus produksi dan konsumsi jarang sekali dapat tepat bertemu. Perusahaan harus memutuskan berapa 
M. Fatkhur Rozi, Reny Rizqy Agatin

banyak dan jenis gudang yang dibutuhkannya dan penempatannya. Semakin banyak gudang yang digunakan perusahaan, maka akan semakin cepat produk mereka akan dikirim ke pelanggan. Namun demikian, lokasi yang lebih banyak berarti biaya pergudangan yang semakin tinggi. Oleh karena itu, perusahaan harus menyeimbangkan tingkat layanan pelanggan dengan biaya distribusi. Penggunaan pergudangan yang tepat dapat membantu mencapai tingkat pelayanan konsumen yang diinginkan (Taff: 1984).

d. Transportasi

Pilihan transportasi mempengaruhi penetapan harga produk, kinerja pengiriman, dan kondisi barang saat barang itu tiba. Dalam memilih suatu model transportasi untuk suatu produk, para pengirim harus menyadari adanya beberapa kriteria transportasi yaitu kereta api, truk, kapal laut dan pesawat. Menurut Taff (1984) transportasi merupakan komponen penting dan yang paling banyak memakan biaya dalam manajemen distribusi fisik.

\section{Least Cost Method}

Menurut Siswanto (2007) metode biaya terkecil (least cost method) adalah sebuah metode untuk menyusun tabel awal dengan cara pengalokasian distribusi barang dari sumber ke tujuan mulai dari model yang memiliki biaya distribusi terkecil. Penguraian yang lebih sistematis yang ditunjukkan dengan suatu prosedur yang dapat menguraikan metode least cost atau least square yang lebih umum langkah-langkahnya adalah sebagai berikut:

a. Pertama

Bentuk tabel inisial dari transportasi dengan memasukkan data yang sudah diperoleh dari persoalan yang ada, seperti pada pengisian kotak-kotak kecil dengan biaya transportasi, total komoditas dimasukkan pada supply dan demand dan seterusnya.

b.Kedua

Pilih biaya atau nilai terkecil pada kotak-kotak kecil dari kotak tabel transportasi. Bila terdapat kesamaan pada nilai kotak kecil maka pilih total komoditas terbanyak dari supply dan demand dengan memperhatikan kondisi muatan komoditas transportasi yang seimbang.

c. Ketiga

Setelah biaya atau nilai terkecil pada kotak kecil tabel transportasi dipilih maka isi nilai komoditas pada kotak transportasi yang ada di dalamnya terdapat kotak kecil tersebut. Pengisian kotak ini dilakukan dengan mempertimbangkan total komoditas supply dan demand.

d. Keempat

Bila kotak transportasi sudah terisi dengan komoditas yang memadai maka kemudian dilakukan pencoretan baris atau kolom yang melalui kotak tabel transportasi sesuai keseimbangan supply dan demand dengan 
menggunakan garis lurus.

e. Kelima

Kembali pada langkah kedua dengan memilih biaya atau nilai terkecil pada kotak-kotak transportasi yang tersisa dimana garis lurus pada garis atau kolom belum ada.

Prosedur ini selesai secara lengkap bila hanya ada satu baris dan satu kolom yang tersisa sehingga hasilnya dapat ditentukan dengan baik. Prosedur metode least cost ini dapat dipergunakan pada setiap model transportasi dengan mempertimbangkan optimalisasi dan kelayakan penyelesaiannya.

\section{Vogel's Approximation Method}

Menurut Siswanto (2007) Vogel's Approximation Method atau VAM adalah metode untuk penentuan tabel awal algoritma transportasi. Vogel's Approximation Method menentukan alokasi distribusi pada sel yang memiliki Cij terkecil dan terletak pada baris atau kolom yang memiliki nilai terbesar dari selisih Cij terkecil.

Menurut Kakiay (2008) Vogel's Approximation Method pada umumnya metode ini dapat memberikan solusi permulaan yang lebih baik daripada kedua metode lainnya, seperti metode north west corner dan metode russel. Dalam kenyataannya VAM dapat menghasilkan solusi permulaan yang optimal atau mendekati optimal. Dalam metode ini dilakukan langkah-langkah prosedural sebagaimana yang diuraikan berikut ini:

a. Pertama

Lakukan evaluasi pengerti untuk setiap baris dan kolom melalui pengurangan dua nilai terkecil dari biaya (pada kotak kecil) pada baris dan kolom yang sama dan kemudian catat hasilnya.

b. Kedua

Identifikasi baris atau kolom dari catatan tersebut dengan mengambil penalti terbesar. Sedapat mungkin alokasikan nilai terbesar pada kotak transportasi dengan biaya terkecil pada kotak kecil dari seleksi baris dan kolom yang sudah terpilih. Perubahan kemudian dilakukan pada baris dan kolom supply dan demand yang mengalami perubahan angka tersebut. c. Ketiga

Lakukan penghapusan pada baris atau kolom terpilih dan yang sudah diproses secara simultan. Bila hanya baris atau kolom yang terhapus maka baris supply dan demand akan menjadi nol (zero). Perlu diperhatikan bahwa setiap baris atau kolom dengan nilai nol pada supply atau demand tidak diperbolehkan untuk digunakan dalam kompensasi penalti selanjutnya.

d. Keempat

Dilakukan pernyataan sebagai berikut:

Bila ternyata satu baris atau satu kolom tidak dapat dihapus maka dapat 
M. Fatkhur Rozi, Reny Rizqy Agatin

langsung dihentikan.

Bila hanya satu baris atau kolom dengan supply dan demand yang positif sebagai sisa dari penghapusan, selidiki variabel basis dalam baris atau kolom dengan menggunakan metode least cost.

Bila semua baris dan kolom yang tidak terhapus dan yang mempunyai nilai nol supply dan demand, selidiki variabel baris nol melalui metode least cost dan dapat langsung dihentikan.

Kalau tidak demikian maka kembali lakukan komputasi melalui penalti untuk baris dengan kolom yang tidak terhapus dan selanjuutnya kembali pada langkah kedua. Memperhatikan bahwa setiap baris dan kolom dari supply dan demand supply dan demandyang sudah bernilai nol tidak dibolehkan menggunakan penalti.

\section{Model Rute Terpendek}

Model rute terpendek (shortest route) adalah salah satu model jaringan yang dapat digunakan untuk menentukan jarak terpendek dari berbagai alternatif rute yang tersedia. Dalam hal ini, istilah rute tidak harus selalu dikaitkan dengan jarak, missal dengan biaya atau waktu.

Model ini sebenarnya bisa dikatakan sebagai variasi gabungan antara model distribusi terkendali dengan model rentang jaringan minimum. Bila model distribusi terkendali ingin memecahkan persoalan penemuan biaya distribusi total minimum maka model rentang jaringan minimum ingin memecahkan persoalan rentang jaringan total minimum. Dalam hal ini, model rute terpendek ingin memecahkan persoalan jarak total minimum. Tujuan yang hendak dicapai pada model rute terpendek adalah peminimuman jarak, biaya atau waktu perjalanan total dari noda awal ke noda akhir.

\section{Metodologi Penelitian}

Jenis dan pendekatan penelitian yang digunakan dalam penelitian ini adalah penelitian kuantitatif deskriptif. Penelitian ini dilakukan pada industri UMKM kerupuk ikan tengiri Desa Gedangan, Kecamatan Kutorejo, Kabupaten Mojokerto periode Mei-Juni 2018. Populasi dalam penelitian ini adalah seluruh UMKM kerupuk ikan tengiri dengan jumlah sampel sebanyak 31 pelaku UMKM. Teknik pengambilan sampel untuk penelitian ini menggunakan teknik sampel jenuh (sensus).dalam penelitian ini data primer dan sekunder diperoleh dari hasil survei dan wawancara.

Survei lapangan dan wawancara kepada 31 pelaku UMKM kerupuk ikan tengiri Desa Gedangan, Kecamatan Kutorejo, Kabupaten Mojokerto diperoleh data mengenai model saluran distribusi setiap UMKM kerupuk ikan tengiri yang ada. Analisis data dalam penelitian ini yaitu melalui pendekatan matematis yang bertujuan untuk menyederhanakan hasil olah data sehingga 
mudah untuk dibaca dan diinterpretasikan.

\section{Hasil Penelitian}

\section{Metode Least Cost}

UMKM Kategori 1

Tabel 1. Jumlah Permintaan UMKM Kategori 1

\begin{tabular}{llll}
\hline GUDANG & \multicolumn{2}{c}{ UMKM 1 } & DEMAND \\
\hline \multirow{4}{*}{ TUJUAN } & Mojokerto & $50.000 \mathrm{~kg}$ & \multirow{2}{*}{$50.000 \mathrm{~kg}$} \\
& Rp. 50 & \\
& Sidoarjo & $50.000 \mathrm{~kg}$ & \\
& Rp. 100 & $50.000 \mathrm{~kg}$ \\
& Surabaya & $64.500 \mathrm{~kg}$ & \\
& Rp. 150 & $64.500 \mathrm{~kg}$ \\
& & & \\
& SUPPLY & $64.500 \mathrm{~kg}$ & $64.500 \mathrm{~kg}$ \\
\hline
\end{tabular}

Sumber: Data diolah

Biaya angkutan kerupuk ikan tengiri dari gudang ke kota tujuan adalah sebagai berikut:

$$
\begin{array}{ll}
\text { Mojokerto } & \text { : Rp. } 50 \times 50.000 \mathrm{~kg}=\text { Rp. } 2.500 .000 \\
\text { Sidoarjo } & \text { : Rp. } 100 \times 50.000 \mathrm{~kg}=\text { Rp. } 5.000 .000 \\
\text { Surabaya } & \text { : Rp. } 150 \times 64.500 \mathrm{~kg}=\text { Rp. } 9.675 .000 \\
\text { Total biaya } & =\text { Rp. } 2.500 .000+\text { Rp. } 5.000 .000+\text { Rp. } 9.675 .000 \\
& =\text { Rp. } 17.175 .000
\end{array}
$$

\section{Kategori 2}

\begin{tabular}{cccc}
\multicolumn{4}{c}{ Tabel 2. Jumlah Permintaan UMKM Kategori 2 } \\
\hline GUDANG & \multicolumn{2}{c}{ UMKM 2 } & DEMAND \\
\hline \multirow{4}{*}{ Mojokerto } & $80.000 \mathrm{~kg}$ & \multirow{2}{*}{$80.000 \mathrm{~kg}$} \\
& & Rp. 50 & \\
TUJUAN & Surabaya & $90.000 \mathrm{~kg}$ & $90.000 \mathrm{~kg}$ \\
& & Rp. 100 & \\
& Pasuruan & $79.000 \mathrm{~kg}$ & $79.000 \mathrm{~kg}$ \\
& & Rp. 100 & \\
& Malang & $80.000 \mathrm{~kg}$ & $80.000 \mathrm{~kg}$ \\
& RuP. 200 & $329.000 \mathrm{~kg}$ \\
\hline
\end{tabular}

Sumber: Data diolah 
M. Fatkhur Rozi, Reny Rizqy Agatin

Biaya angkutan kerupuk ikan tengiri dari gudang ke kota tujuan adalah sebagai berikut:

$$
\begin{array}{ll}
\text { Mojokerto } & \text { : Rp. } 50 \times 80.000 \mathrm{~kg}=\text { Rp. } 4.000 .000 \\
\text { Surabaya } & \text { : Rp. } 100 \times 90.000 \mathrm{~kg}=\text { Rp. } 9.000 .000 \\
\text { Pasuruan } & \text { : Rp. } 100 \times 79.000 \mathrm{~kg}=\text { Rp. } 7.900 .000 \\
\text { Malang } & \text { : Rp. } 200 \times 80.000 \mathrm{~kg}=\text { Rp. } 1.000 .000 \\
\text { Total biaya = Rp. } 4.000 .000+\text { Rp. } 9.000 .000+\text { Rp. } 7.900 .000+\text { Rp. } \\
\begin{array}{l}
16.000 .000 \\
\end{array} \\
=\text { Rp. } 36.900 .000
\end{array}
$$

\begin{tabular}{|c|c|}
\hline Mojokerto & : Rp. $50 \times 90.000 \mathrm{~kg}=$ Rp. 4.500 .000 \\
\hline Surabaya & : Rp. $100 \times 90.000 \mathrm{~kg}=$ Rp. 9.000 .000 \\
\hline Madura & : Rp. 200 x 100.000 kg= Rp. 20.000 .000 \\
\hline Malang & : Rp. 200 x $123.500 \mathrm{~kg}=$ Rp. 24.700 .000 \\
\hline Jember & : Rp. $300 \times 90.000 \mathrm{~kg}=$ Rp. 27.000 .000 \\
\hline $\begin{array}{l}\text { Total biaya } \\
+ \text { Rp. } 24.700\end{array}$ & $\begin{array}{l}=\text { Rp. } 4.500 .000+\text { Rp. } 9.000 .000+\text { Rp. } 20.000 .000 \\
0+\text { Rp. } 27.000 .000\end{array}$ \\
\hline & $=$ Rp. 85.200.000 \\
\hline
\end{tabular}

\section{Kategori 3}

Tabel 3. Jumlah Permintaan UMKM Kategori 3

\begin{tabular}{cccc}
\hline GUDANG & \multicolumn{2}{c}{ UMKM 3 } & DEMAND \\
\hline & \multirow{2}{*}{ Mojokerto } & $90.000 \mathrm{~kg}$ & \multirow{2}{*}{ Rp. $50.000 \mathrm{~kg}$} \\
& & $90.000 \mathrm{~kg}$ & \\
& Surabaya & Rp. 100 & $90.000 \mathrm{~kg}$ \\
& & $100.000 \mathrm{~kg}$ & \\
TUJUAN & Madura & Rp. 200 & $100.000 \mathrm{~kg}$ \\
& & $123.500 \mathrm{~kg}$ & \\
& Malang & Rp. 200 & $123.500 \mathrm{~kg}$ \\
& & $90.000 \mathrm{~kg}$ & \\
& Jember & Rp. 300 & $90.000 \mathrm{~kg}$ \\
& SUPPLY & Rp. 493.500 & Rp. 493.500 \\
\hline
\end{tabular}

Sumber: Data diolah

Biaya angkutan kerupuk ikan tengiri dari gudang ke kota tujuan adalah sebagai berikut: 


\section{Kategori 4}

Analisis Efisiensi Saluran Distribusi...

Tabel 4. Jumlah Permintaan UMKM Kategori 4

\begin{tabular}{|c|c|c|c|}
\hline GUDANG & \multicolumn{2}{|c|}{ UMKM 4} & DEMAND \\
\hline \multirow{8}{*}{ TUJUAN } & Mojokerto & $\begin{array}{l}130.500 \mathrm{~kg} \\
\text { Rp. } 50\end{array}$ & $130.500 \mathrm{~kg}$ \\
\hline & Surabaya & $\begin{array}{l}120.000 \mathrm{~kg} \\
\text { Rp. } 100\end{array}$ & $120.000 \mathrm{~kg}$ \\
\hline & Madura & $\begin{array}{l}120.000 \mathrm{~kg} \\
\text { Rp. } 200\end{array}$ & $120.000 \mathrm{~kg}$ \\
\hline & Kalimantan & $\begin{array}{l}100.000 \mathrm{~kg} \\
\text { Rp. } 1.500\end{array}$ & $100.000 \mathrm{~kg}$ \\
\hline & Magetan & $\begin{array}{l}152.000 \mathrm{~kg} \\
\text { Rp. } 400\end{array}$ & $152.000 \mathrm{~kg}$ \\
\hline & Malang & $\begin{array}{l}130.000 \mathrm{~kg} \\
\text { Rp. } 200\end{array}$ & $130.000 \mathrm{~kg}$ \\
\hline & Banyuwangi & $\begin{array}{c}130.000 \mathrm{~kg} \\
\text { Rp. } 450\end{array}$ & $130.000 \mathrm{~kg}$ \\
\hline & SUPPLY & Rp. 882.500 & Rp. 882.500 \\
\hline
\end{tabular}

Sumber: Data diolah

Biaya angkutan kerupuk ikan tengiri dari gudang ke kota tujuan adalah:

Mojokerto : Rp. $50 \times 130.500 \mathrm{~kg}=$ Rp. 6.525 .000

Surabaya : Rp. $100 \times 120.000 \mathrm{~kg}=$ Rp. 12.000 .000

Madura : Rp. $200 \times 120.000 \mathrm{~kg}=$ Rp. 24.000 .000

Kalimantan : Rp. $1.500 \times 100.000$ kg= Rp. 150.000 .000

Magetan : Rp. $400 \times 152.000=$ Rp. 60.800 .000

Malang : Rp. $200 \times 130.000 \mathrm{~kg}=$ Rp. 26.000 .000

Banyuwangi : Rp. $450 \times 130.000 \mathrm{~kg}=$ Rp. 58.500 .000

Total biaya $\quad=$ Rp. $6.525 .000+$ Rp. $12.000 .000+$ Rp. $24.000 .000+$ Rp.

$150.000 .000+$ Rp. $60.800 .000+$ Rp. $26.000 .000+$ Rp.

58.500 .000

$=$ Rp. 337.825 .000

\section{Metode Vogel's}

Kategori 1

Tabel 5. Jumlah Permintaan UMKM Kategori 1

\begin{tabular}{cccc}
\hline GUDANG & \multicolumn{2}{c}{ UMKM 1 } & DEMAND \\
\hline \multirow{6}{*}{ TUJUAN } & Mojokerto & $50.000 \mathrm{~kg}$ & $50.000 \mathrm{~kg}$ \\
& & Rp. 50 & \\
& Sidoarjo & $50.000 \mathrm{~kg}$ & $50.000 \mathrm{~kg}$ \\
& & Rp. 100 & \\
& Surabaya & $64.500 \mathrm{~kg}$ & \\
& Rp. 150 & $64.500 \mathrm{~kg}$ \\
& SUPPLY & $164.500 \mathrm{~kg}$ & $164.500 \mathrm{~kg}$ \\
\hline
\end{tabular}

Sumber: Data diolah 
Biaya angkutan kerupuk ikan tengiri dari gudang ke kota tujuan adalah sebagai berikut:

Mojokerto

: Rp. $50 \times 50.000 \mathrm{~kg}=$ Rp. 2.500 .000

Sidoarjo

: Rp. $100 \times 50.000 \mathrm{~kg}=$ Rp. 5.000 .000

Surabaya

: Rp. $150 \times 64.500 \mathrm{~kg}=\mathrm{Rp} .9 .675 .000$

Total biaya = Rp. $2.500 .000+$ Rp. $5.000 .000+$ Rp. 9.675 .000 $=$ Rp. 17.175 .000

\section{Kategori 2}

Tabel 6. Jumlah Permintaan UMKM Kategori 2

\begin{tabular}{cccc}
\hline GUDANG & \multicolumn{2}{c}{ UMKM 2 } & DEMAND \\
\hline \multirow{4}{*}{ TUJUAN } & Mojokerto & $80.000 \mathrm{~kg}$ & \multirow{2}{*}{$80.000 \mathrm{~kg}$} \\
& & Rp. 50 & \\
& & $90.000 \mathrm{~kg}$ & \\
& Surabaya & Rp. 100 & $90.000 \mathrm{~kg}$ \\
& Pasuruan & $79.000 \mathrm{~kg}$ & \\
& & Rp. 100 & $79.000 \mathrm{~kg}$ \\
& Malang & $80.000 \mathrm{~kg}$ & \\
& Rp. 200 & $80.000 \mathrm{~kg}$ \\
& SUPPLY & $329.000 \mathrm{~kg}$ & $329.000 \mathrm{~kg}$ \\
\hline
\end{tabular}

Sumber: Data diolah

Biaya angkutan kerupuk ikan tengiri dari gudang ke kota tujuan adalah sebagai berikut:

Mojokerto : Rp. $50 \times 80.000 \mathrm{~kg}=$ Rp. 4.000 .000

Surabaya $\quad$ :Rp. $100 \times 90.000 \mathrm{~kg}=\mathrm{Rp} .9 .000 .000$

Pasuruan : Rp. $100 \times 79.000 \mathrm{~kg}=$ Rp. 7.900 .000

Malang : Rp. $200 \times 80.000 \mathrm{~kg}=$ Rp. 1.000 .000

Total biaya $\quad=$ Rp. $4.000 .000+$ Rp. $9.000 .000+$ Rp. $7.900 .000+$ Rp. 16.000 .000

$=$ Rp. 36.900 .000

Kategori 3

Tabel 7. Jumlah Permintaan UMKM Kategori 3

\begin{tabular}{|c|c|c|c|}
\hline GUDANG & & KM 3 & DEMAND \\
\hline \multirow{6}{*}{ TUJUAN } & Mojokerto & $\begin{array}{l}90.000 \mathrm{~kg} \\
\text { Rp. } 50\end{array}$ & $90.000 \mathrm{~kg}$ \\
\hline & Surabaya & $\begin{array}{l}90.000 \mathrm{~kg} \\
\text { Rp. } 100\end{array}$ & $90.000 \mathrm{~kg}$ \\
\hline & Madura & $\begin{array}{l}100.000 \mathrm{~kg} \\
\text { Rp. } 200\end{array}$ & $100.000 \mathrm{~kg}$ \\
\hline & Malang & $\begin{array}{l}123.500 \mathrm{~kg} \\
\text { Rp. } 200\end{array}$ & $123.500 \mathrm{~kg}$ \\
\hline & Jember & $\begin{array}{l}90.000 \mathrm{~kg} \\
\text { Rp. } 300\end{array}$ & $90.000 \mathrm{~kg}$ \\
\hline & SUPPLY & Rp. 493.500 & Rp. 493.500 \\
\hline
\end{tabular}

Sumber: Data diolah 
Biaya angkutan kerupuk ikan tengiri dari gudang ke kota tujuan adalah sebagai berikut:

Mojokerto

Surabaya

Madura

Malang

Jember

Total biaya

:Rp. $50 \times 90.000 \mathrm{~kg}=$ Rp. 4.500 .000

:Rp. $100 \times 90.000 \mathrm{~kg}=$ Rp. 9.000 .000

: Rp. $200 \times 100.000 \mathrm{~kg}=$ Rp. 20.000 .000

:Rp. $200 \times 123.500 \mathrm{~kg}=$ Rp. 24.700 .000

:Rp. $300 \times 90.000 \mathrm{~kg}=$ Rp. 27.000 .000

$=$ Rp. $4.500 .000+$ Rp. $9.000 .000+$ Rp. $20.000 .000+$

Rp. $24.700 .000+$ Rp. 27.000 .000

$=$ Rp. 85.200 .000

\section{Kategori 4}

Tabel 8. Jumlah Permintaan UMKM Kategori 4

\begin{tabular}{|c|c|c|c|}
\hline GUDANG & \multicolumn{2}{|c|}{ UMKM 4} & DEMAND \\
\hline \multirow{8}{*}{ TUJUAN } & Mojokerto & $\begin{array}{l}130.500 \mathrm{~kg} \\
\text { Rp. } 50\end{array}$ & $130.500 \mathrm{~kg}$ \\
\hline & Surabaya & $\begin{array}{l}120.000 \mathrm{~kg} \\
\text { Rp. } 100\end{array}$ & $120.000 \mathrm{~kg}$ \\
\hline & Madura & $\begin{array}{l}120.000 \mathrm{~kg} \\
\text { Rp. } 200\end{array}$ & $120.000 \mathrm{~kg}$ \\
\hline & Kalimantan & $\begin{array}{l}100.000 \mathrm{~kg} \\
\text { Rp. } 1.500\end{array}$ & $100.000 \mathrm{~kg}$ \\
\hline & Magetan & $\begin{array}{l}152.000 \mathrm{~kg} \\
\text { Rp. } 400\end{array}$ & $152.000 \mathrm{~kg}$ \\
\hline & Malang & $\begin{array}{l}130.000 \mathrm{~kg} \\
\text { Rp. } 200\end{array}$ & $130.000 \mathrm{~kg}$ \\
\hline & Banyuwangi & $\begin{array}{l}130.000 \mathrm{~kg} \\
\text { Rp. } 450\end{array}$ & $130.000 \mathrm{~kg}$ \\
\hline & SUPPLY & Rp. 882.500 & Rp. 882.500 \\
\hline
\end{tabular}

Biaya angkutan kerupuk ikan tengiri dari gudang ke kota tujuan adalah sebagai berikut:

$\begin{array}{ll}\text { Mojokerto } & \text { : Rp. } 50 \times 130.500 \mathrm{~kg}=\text { Rp. } 6.525 .000 \\ \text { Surabaya } & : \text { Rp. } 100 \times 120.000 \mathrm{~kg}=\text { Rp. } 12.000 .000 \\ \text { Madura } & : \text { Rp. } 200 \times 120.000 \mathrm{~kg}=\text { Rp. } 24.000 .000 \\ \text { Kalimantan } & : \text { Rp. } 1.500 \times 100.000 \mathrm{~kg}=\text { Rp. } 150.000 .000 \\ \text { Magetan } & : \text { Rp. } 400 \times 152.000=\text { Rp. } 60.800 .000 \\ \text { Malang } & : \text { Rp. } 200 \times 130.000 \mathrm{~kg}=\text { Rp. } 26.000 .000 \\ \text { Banyuwangi } & \text { : Rp. } 450 \times 130.000 \mathrm{~kg}=\text { Rp. } 58.500 .000 \\ \text { Total biaya } & =\text { Rp. } 6.525 .000+\text { Rp. } 12.000 .000+\text { Rp. } 24.000 .000+ \\ & \text { Rp. } 150.000 .000+\text { Rp. } 60.800 .000+\text { Rp. } 26.000 .000+ \\ & \text { Rp. } 58.500 .000 \\ & =\text { Rp. } 337.825 .000\end{array}$




\section{Metode Rute Jarak Terpendek}

\section{Kategori 1}

Berdasarkan hasil wawancara, didapatkan bahwa jalur distribusi UMKM kategori 1 memiliki pola AA - AB - AC. Kondisi lapangan jaringan distribusi yang diterapkan oleh UMKM kerupuk ikan tengiri kategori 1 ini dapat digambarkan sebagai berikut:

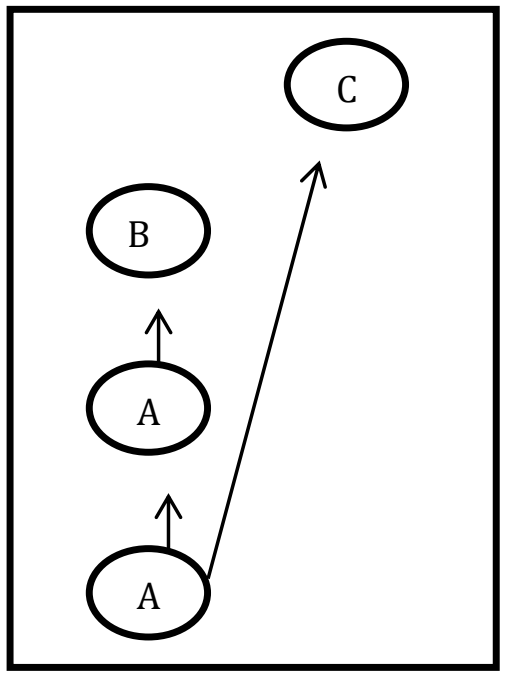

\section{Gambar 1. Rute Awal Jalur Distribusi UMKM Kategori 1}
Keterangan:
A: Mojokerto
B: Sidoarjo
C: Surabaya

Total biaya transportasi yang dikeluarkan oleh UMKM kategori 1 untuk menyelasaikan model distibusi dengan pola $\mathrm{AA}$ - AB- AC adalah sebagai berikut:

Biaya Minimal $=50 \mathrm{XAA}+50 \mathrm{XAB}+150 \mathrm{XAC}$

Biaya Minimal $=($ Rp. $50 \times 50.000 \mathrm{~kg})+($ Rp. $50 \times 50.000 \mathrm{~kg})+($ Rp. $150 \mathrm{x}$ $64.500 \mathrm{~kg}$ )

Biaya Minimal $=$ Rp. $2.500 .000+$ Rp. $2.500 .000+$ Rp. 9.675 .000

Biaya Minimal $=$ Rp. 14.675 .000

Berdasarkan model saluran distribusi awal tersebut, maka peneliti memberikan model saluran distribusi dengan biaya yang paling minimum sebagai berikut: 


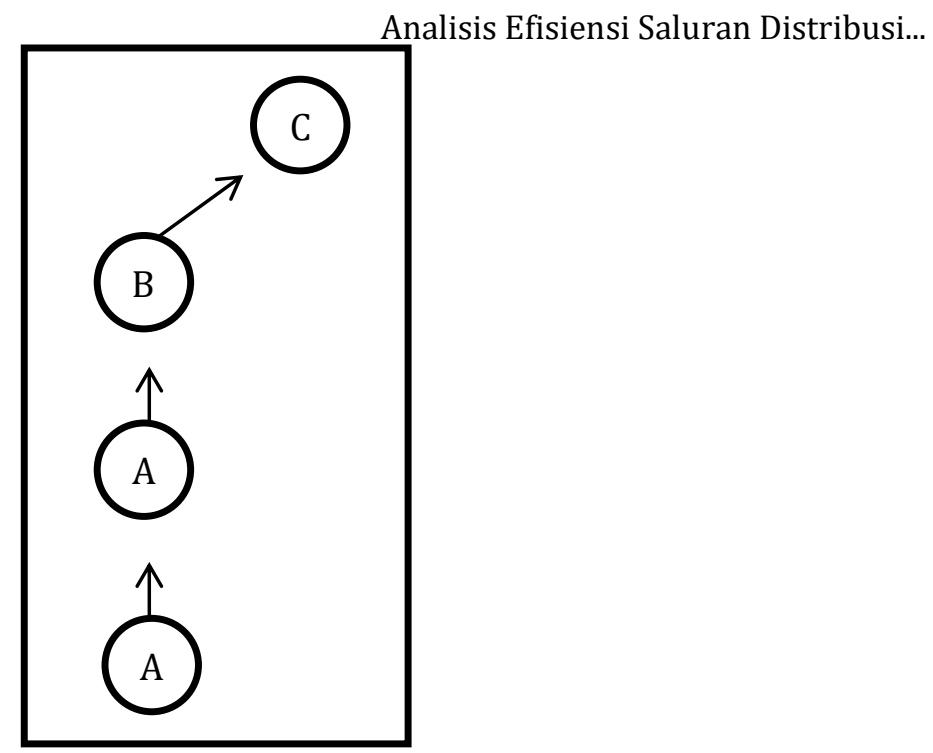

\section{Gambar 2. Rute Efisien Jalur Distribusi UMKM Kategori 1}

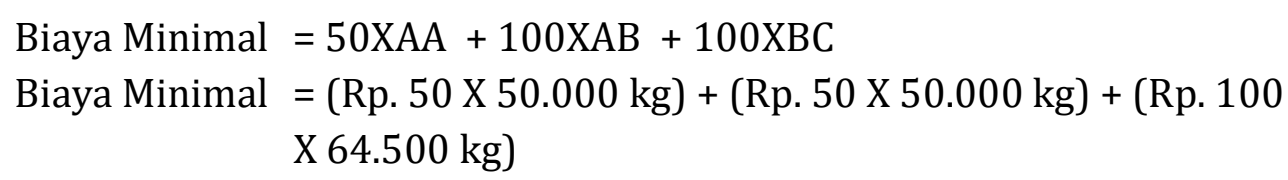

Biaya Minimal = Rp. $2.500 .000+$ Rp. $2.500 .000+$ Rp. 6.450 .000

Biaya Minimal $=$ Rp. 11.450 .000

Jalur transportasi dengan rute terpendek yaitu pada noda AB- BC- CD dengan biaya minimal sebesar Rp. 11.450.000.

Jadi, jalur transportasi UMKM kategori 1 yang paling efisien adalah dengan rute $A A-A B-B C$ dengan biaya minimal sebesar Rp. 11.450.000, sedangkan rute awal AA- AB- AC yang diterapkan oleh UMKM kategori 1 dengan biaya minimal sebesar Rp. 14.675.000. Hal ini berarti, rute AA- AB- BC

lebih efisien daripada rute AA- AB- AC dengan penghematan biaya sebesar Rp. 3.225.000.

\section{Kategori 2}

Berdasarkan hasil wawancara, didapatkan bahwa jalur distribusi UMKM kategori 2 adalah AB - AA - AC - AD. Kondisi lapangan jaringan distribusi yang diterapkan oleh UMKM kerupuk ikan tengiri kategori 2 ini dapat digambarkan sebagai berikut: 


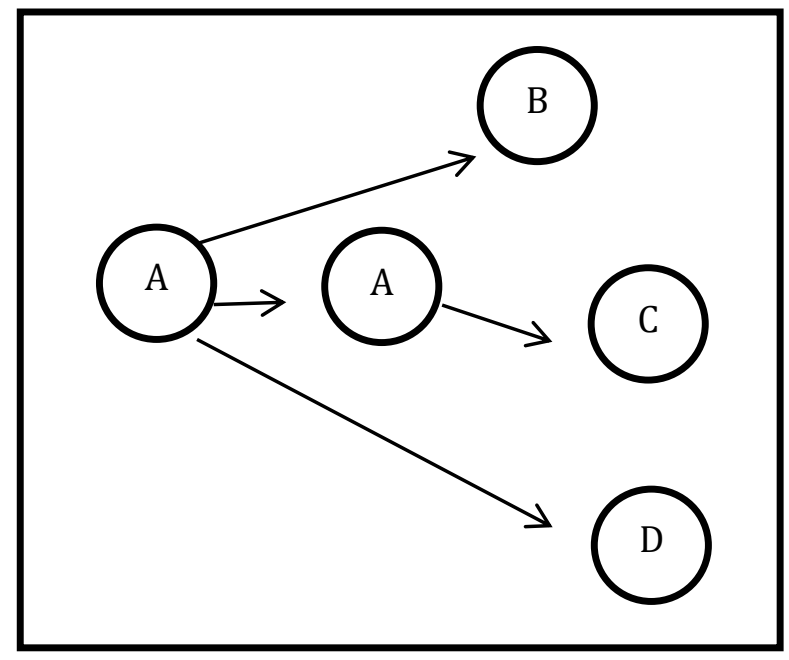

\section{Gambar 3. Rute Awal Jalur Distribusi UMKM Kategori 2}

Keterangan:
A: Mojokerto
B: Surabaya
C: Pasuruan
D: Malang

Total biaya transportasi yang dikeluarkan oleh UMKM kategori 2 untuk menyelasaikan model distibusinya dengan pola $\mathrm{AB}$ - $\mathrm{AA}$ - AC - AD adalah sebagai berikut:

$$
\begin{aligned}
\text { Biaya Minimal } & =100 \mathrm{XAB}+50 \mathrm{XAA}+50 \mathrm{XAC}+200 \mathrm{XAD} \\
\text { Biaya Minimal } & =(\text { Rp. } 100 \times 90.000 \mathrm{~kg})+(\text { Rp. } 50 \times 80.000 \mathrm{~kg})+(\text { Rp. } 50 \\
& \times 79.000 \mathrm{~kg})+(\text { Rp. } 200 \times 80.000 \mathrm{~kg})
\end{aligned}
$$

Biaya Minimal $=$ Rp. $9.000 .000+$ Rp. $4.000 .000+$ Rp. $3.950 .000+$ Rp. 16.000 .000

Biaya Minimal $=$ Rp. 32.950 .000

Berdasarkan model saluran distribusi awal tersebut, maka peneliti memberikan model saluran distribusi dengan biaya yang paling minimum sebagai berikut: 


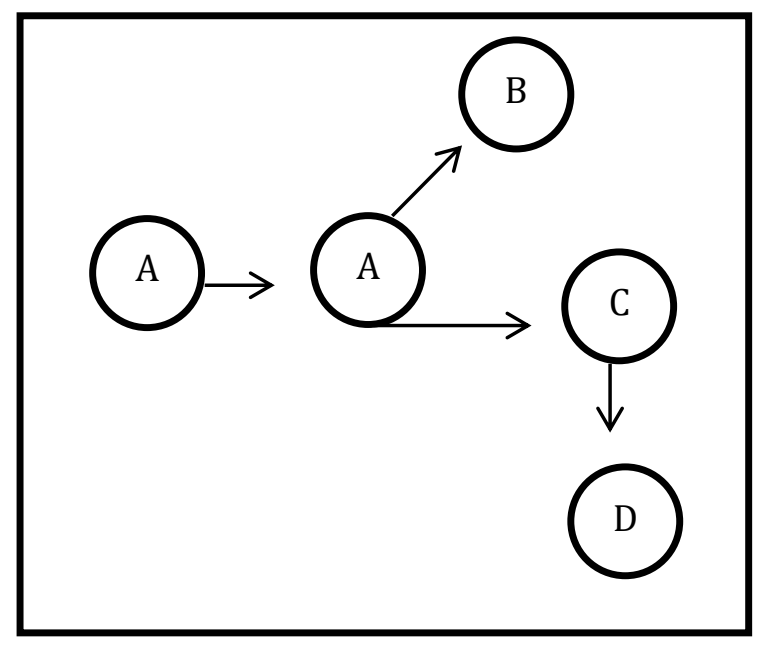

\section{Gambar 4. Rute Efisien Jalur Distribusi UMKM Kategori 2}

$$
\begin{aligned}
\text { Biaya Minimal } & =50 X A A+50 X A B+100 X A C+100 X C D \\
\text { Biaya Minimal } & =(\text { Rp. } 50 \times 80.000 \mathrm{~kg})+(\text { Rp. } 50 \times 90.000 \mathrm{~kg})+(\text { Rp. } 100 \\
& \text { x } 79.000 \mathrm{~kg})+(\text { Rp. } 100 \times 80.000 \mathrm{~kg}) \\
\text { Biaya Minimal } & =\text { Rp. } 4.000 .000+\text { Rp. } 4.500 .000+\text { Rp. } 7.900 .000+\text { Rp. } \\
& 8.000 .000
\end{aligned}
$$

Biaya Minimal = Rp. 24.400.000

Jalur transportasi dengan rute terpendek yaitu pada noda AA- AB- ACCD dengan biaya minimal sebesar Rp. 24.400.000

Jadi, jalur transportasi UMKM kategori 2 yang paling efisien adalah dengan rute AA- AB- AC- $C D$ dengan biaya minimal sebesar Rp. 24.400.000, sedangkan rute awal AB - AA - AC - AD yang diterapkan oleh UMKM kategori 2 dengan biaya minimal sebesar Rp. 32.950.000. Hal ini berarti, rute AA- AB- ACCD lebih efisien daripada rute $\mathrm{AB}$ - AA - AC - AD dengan penghematan biaya sebesar Rp. 8.550.000.

\section{Kategori 3}

Berdasarkan hasil wawancara, didapatkan bahwa jalur distribusi UMKM kategori 3 adalah AA - AB - BC - AD - DE. Kondisi lapangan jaringan distribusi yang diterapkan oleh UMKM kerupuk ikan tengiri kategori 3 ini dapat digambarkan sebagai berikut: 


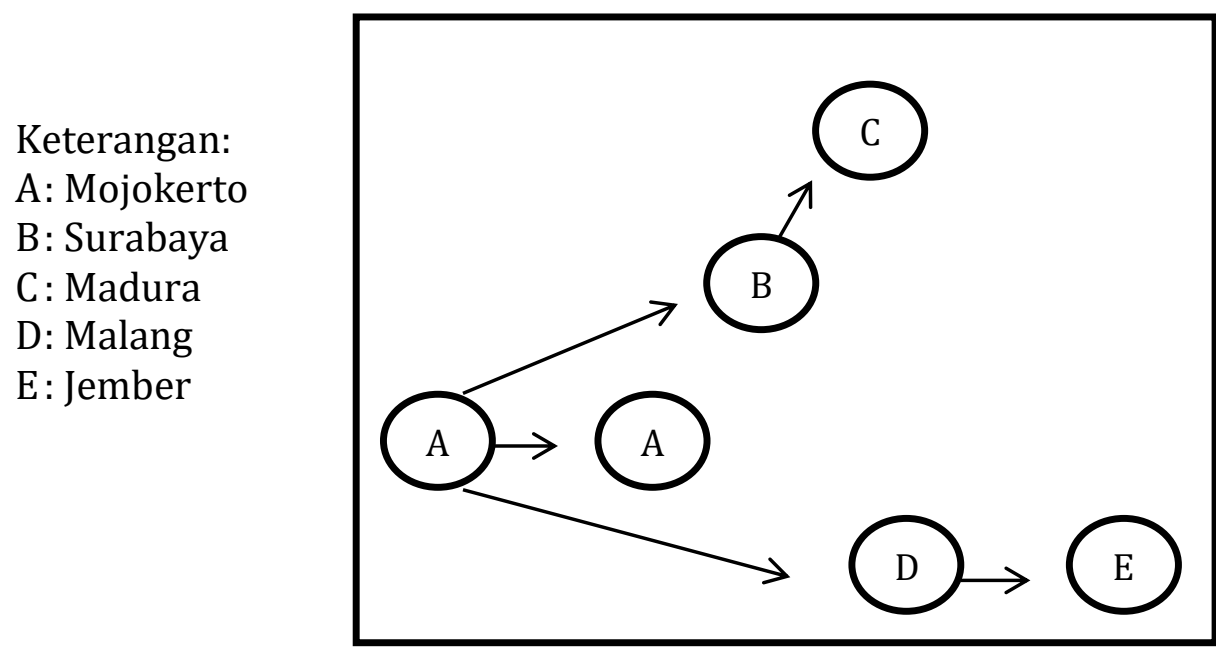

\section{Gambar 5. Rute Awal Jalur Distribusi UMKM Kategori 3}

Total biaya transportasi yang dikeluarkan oleh UMKM kategori 3 untuk menyelasaikan model distibusinya dengan pola pola $A A-A B-B C-A D-D E$ adalah sebagai berikut:

Biaya Minimal $=50 \mathrm{XAA}+100 \mathrm{XAB}+100 \mathrm{XBC}+200 \mathrm{XAD}+100 \mathrm{XDE}$

Biaya Minimal $=($ Rp. $50 \times 90.000 \mathrm{~kg})+($ Rp. $100 \times 90.000 \mathrm{~kg})+(\mathrm{Rp}$. $100 \times 100.000 \mathrm{~kg})+($ Rp. $200 \times 123.500 \mathrm{~kg}) \times($ Rp. $100 \times 90.000 \mathrm{~kg})$

Biaya Minimal $=$ Rp. $4.500 .000+$ Rp. $9.000 .000+$ Rp. $10.000 .000+$ Rp. 24.700.000 + Rp. 9.000.000

Biaya Minimal = Rp. 57.200.000

Berdasarkan model saluran distribusi awal tersebut, maka peneliti memberikan model saluran distribusi dengan biaya yang paling minimum sebagai berikut:

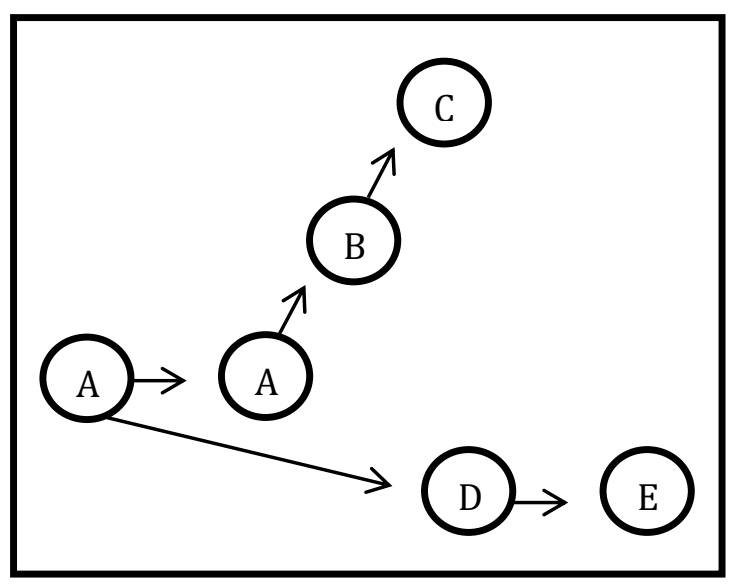

Gambar 6. Rute Efisien Jalur Distribusi UMKM Kategori 3 
Biaya Minimal $=50 \mathrm{XAA}+50 \mathrm{XAB}+100 \mathrm{XBC}+200 \mathrm{XAD}+100 \mathrm{XDE}$

Biaya Minimal $=($ Rp. $50 \times 90.000 \mathrm{~kg})+($ Rp. $50 \times 90.000 \mathrm{~kg})+($ Rp. 100 x $100.000 \mathrm{~kg})+($ Rp. $200 \times 123.500 \mathrm{~kg}) \mathrm{x}($ Rp. $100 \mathrm{x}$ $90.000 \mathrm{~kg})$

Biaya Minimal $=$ Rp. $4.500 .000+$ Rp. $4.500 .000+$ Rp. $10.000 .000+$ Rp. $24.700 .000+$ Rp. 9.000 .000

Biaya Minimal $=$ Rp. 52.700.000

Jalur transportasi dengan rute terpendek yaitu pada noda AA - AB - BC AD - DE dengan biaya minimal sebesar Rp. 52.700.000.

Jadi, jalur transportasi UMKM kategori 3 yang paling efisien adalah dengan rute $A A-A B$ - BC - AD - DE dengan biaya minimal sebesar Rp. 52.700.000, sedangkan rute awal AA - AB (melalui pusat) - BC - AD - DE yang diterapkan oleh UMKM kategori 3 dengan biaya minimal sebesar Rp. 57.200.000. Hal ini berarti, rute AA - AB - BC - AD - DE lebih efisien daripada rute $\mathrm{AA}$ - $\mathrm{AB}$ (melalui pusat) - BC - AD - DE dengan penghematan biaya sebesar Rp. 4.500.000.

\section{Kategori 4}

Berdasarkan hasil wawancara, didapatkan bahwa jalur distribusi UMKM kategori 4 adalah AA - AB - BC - AD - AE - AF - FG Kondisi lapangan jaringan distribusi yang diterapkan oleh UMKM kerupuk ikan tengiri kategori 4 ini dapat digambarkan sebagai berikut:

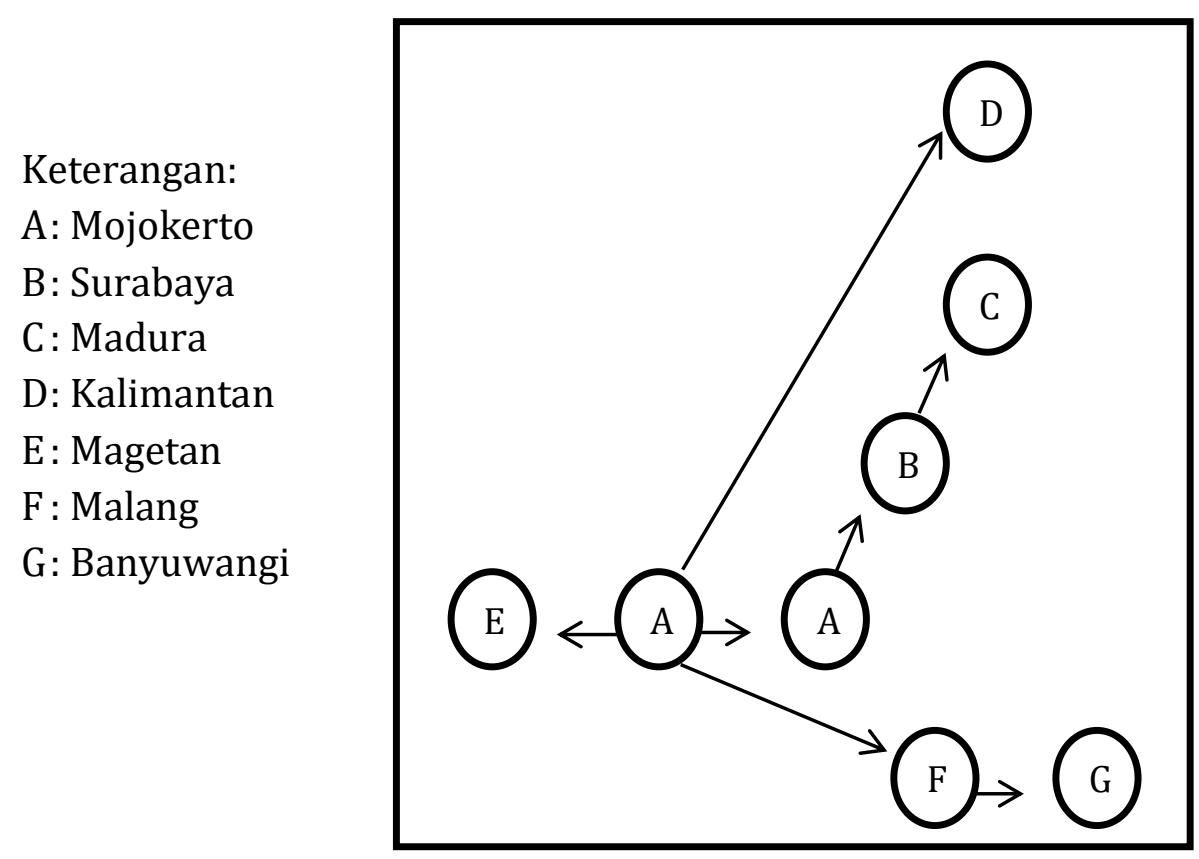

\section{Gambar 7. Rute Awal Jalur Distribusi UMKM Kategori 4}

Total biaya transportasi yang dikeluarkan oleh UMKM kategori 4 untuk menyelasaikan model distibusinya dengan pola $\mathrm{AA}-\mathrm{AB}-\mathrm{BC}-\mathrm{AD}-\mathrm{AE}-\mathrm{AF}-$ 
M. Fatkhur Rozi, Reny Rizqy Agatin

FG adalah sebagai berikut:

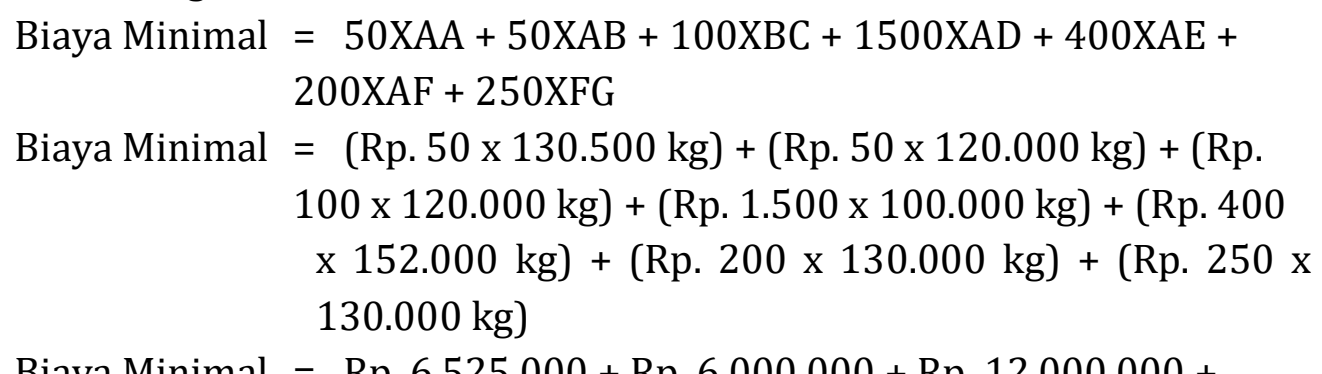

Biaya Minimal = Rp. $6.525 .000+$ Rp. $6.000 .000+$ Rp. $12.000 .000+$ Rp. $150.000 .000+$ Rp. $60.800 .000+$ Rp. $26.000 .000+$ Rp. 32.500 .000

Biaya Minimal $=$ Rp. 293.825.000

Berdasarkan model saluran distribusi awal tersebut, maka peneliti memberikan model saluran distribusi dengan biaya yang paling minimum sebagai berikut:

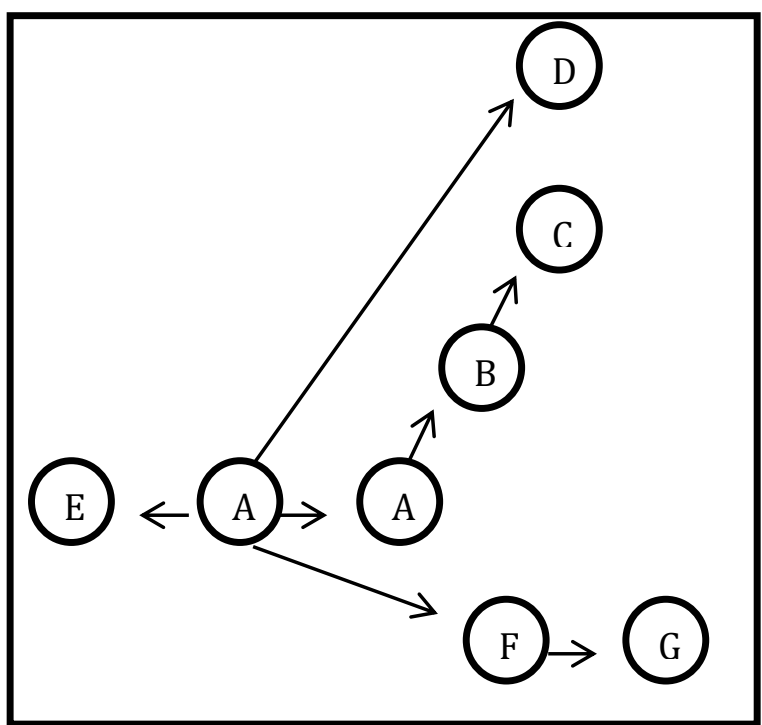

\section{Gambar 8. Rute Efisien Jalur Distribusi UMKM Kategori 4}

Biaya Minimal $=50 \mathrm{XAA}+50 \mathrm{XAB}+100 \mathrm{XBC}+1500 \mathrm{XCD}+400 \mathrm{XAE}+$ $200 X A F+250 X F G$

Biaya Minimal $=($ Rp. $50 \times 130.500 \mathrm{~kg})+($ Rp. $50 \times 120.000 \mathrm{~kg})+(\mathrm{Rp}$. $100 \times 120.000 \mathrm{~kg})+($ Rp. $1.300 \times 100.000 \mathrm{~kg})+($ Rp. 400 x $152.000 \mathrm{~kg})+($ Rp. $200 \times 130.000 \mathrm{~kg})+($ Rp. $250 \mathrm{x}$ $130.000 \mathrm{~kg})$

Biaya Minimal $=$ Rp. $6.525 .000+$ Rp. $6.000 .000+$ Rp. $12.000 .000+$ Rp. $130.000 .000+$ Rp. $60.800 .000+$ Rp. $26.000 .000+$ Rp. 32.500 .000

Biaya Minimal $=$ Rp. 273.825.000

Jadi, jalur transportasi UMKM kategori 4 yang paling efisien adalah 234| IQTISHODUNA Vol. 15 No. 2 Tahun 2019 http://ejournal.uin-malang.ac.id/index.php/ekonomi 
dengan rute $\mathrm{AA}-\mathrm{AB}$ - $\mathrm{BC}-\mathrm{CD}$ - $\mathrm{AE}$ - AF - FG dengan biaya minimal sebesar Rp. 273.825.000. sedangkan rute awal AA - AB - BC - AD - AE - AF - FG yang diterapkan oleh UMKM kategori 4 dengan biaya minimal sebesar Rp. 293.825.000. Hal ini berarti, rute AA - AB - BC - CD - AE - AF - FG lebih efisien daripada rute $A A-A B-B C-A D-A E-A F-F G$ dengan penghematan biaya sebesar Rp. 20.000.000.

\section{Kesimpulan}

Kesimpulan dalam penelitian ini menyebutkan hasil perhitungan yang sama antara metode least cost dan metode vogel's yaitu didapatkan total biaya kategori 1 sebesar Rp 17.1175 .000 dengan jumlah permintaan sebesar $164.500 \mathrm{~kg}$, total biaya kategori 2 sebesar Rp. 32.900 .000 dengan jumlah permintaan sebesar $329.000 \mathrm{~kg}$, total biaya kategori 3 sebesar Rp. 95.225 .000 dengan jumlah permintaan sebesar $493.500 \mathrm{~kg}$ dan total biaya kategori 4 sebesar Rp. 138.750 .000 dengan jumlah permintaan sebesar $882.500 \mathrm{~kg}$. Efisiensi saluran distribusi dengan model rute jarak terpendek kategori 1 dengan rute $\mathrm{AA}-\mathrm{AB}-\mathrm{BC}$ dengan biaya minimal sebesar Rp. 11.450.000, kategori 2 dengan rute AA- AB- AC- $C D$ dengan biaya minimal sebesar Rp. 24.400.000, kategori 3 dengan rute $A A$ - $A B$ - BC - AD - DE dengan biaya minimal sebesar Rp. 52.700.000 dan kategori 4 dengan rute AA - AB - BC - CD - AE - AF - FG dengan biaya minimal sebesar Rp. 273.825.000.

Rekomendasi berdasarkan hasil penelitian, bahwa pencatatan setiap kegiatan yang dijalankan dan keputusan selektif dalam menentukan lokasi tujuan distribusi dengan memerhatikan tingkat permintaan, penawaran serta biaya distribusi.

\section{Daftar Pustaka}

Indrajit, R. E., Djokopranoto, R. 2003. Manajemen Persediaan. Jakarta: PT. Gramedia Widiasarana Indonesia

Juwanto, A. 2012. Analisis Efisiensi Saluran Distribusi Pada Perusahaan Abon KL Noeria Surakarta. Universitas Sebelas Maret.

Kakiay, T.J. 2008. Pemrograman Linier: Metode dan Problematika. Yogyakarta: Andi Offsets

Karo, N. Br. 2016. Analisis Optimasi Distribusi Beras Bulog di Provinsi Jawa Barat. Jurnal Ilmiah Manajemen. Vol. 6 (1). Pp. 103-120.

Kotler, P., Amstrong, G. 1999. Principles of Marketing. Eighth Edition. Prentice Hall, Inc.

Sihombing, D. 2001. Prinsip-prinsip Pemasaran. Edisi Kedelapan. Jakarta: Erlangga.

Nasution, N. 2004. Managemen Transportasi (edisi 2, cet. pertama). Jakarta: Ghalia Indonesia

Ramadhani, A. S. 2017. Analisis Perbandingan Least Cost Method dan Vogell's Approximations untuk Optimasi Transportasi Pengiriman Barang. 
M. Fatkhur Rozi, Reny Rizqy Agatin

Majalah Ilmiah INTI. Vol 12 (2). Pp. 140-145.

Siswanto. 2007. Operations Research. Jilid 1. Jakarta: Erlangga

Taff, Charles A. 1984. Management of Physical Distribution and Transportation. Seventh Edition. Richard D. Irwin, Inc., Maryland.Sinaga, Mariatus (penerjemah, 1994). Manajemen Transportasi dan Distribusi Fisis. Edisi Kedua. Jakarta: Erlangga.

Yusanti, S.M., Dihardjo. W.S., dan Shoffa, S. 2017. Analisis Perbandinagan Pengiriman Barang Menggunakan Metode Nort West Corner dan Least Cost pada PT. Coca Co;a Amatil Indonesia Surabaya. Journal of Mathematics Education, Science and Technology. Vol. 2 (1). Pp. 1-10. 